\title{
Antimicrobial and Photometric assessment of Lawsonia inermis on Oral Bacteria and Tooth Colour
}

\author{
Maryam Nikfallah, DMD ${ }^{1}$, Adith Venugopal, BDS, $\mathrm{MS}^{2}$. \\ ${ }^{1}$ (College of Dentistry, University of the East, Philippines) \\ ${ }^{2}$ (Department of Orthodontics, University of the East, Philippines)
}

\begin{abstract}
Antibacterial agents were one of the major advances of the field of medicine. The main purpose of this study was to measure the effect of Lawsonia inermis on S. mutans and L. acidophilus as plaque inducer and pathogenic bacterium. Lawsonia inermis extract serially diluted in sterile MRS broth from in range of $50 \%$ to $0.4 \%$ in $5 \mathrm{ml}$ sterile test tubes with cotton plug were used. Plant extracts were mixed with MRS Broth as a stock solution and bacterial suspension $\left(1 \times 10^{7} \mathrm{cfu} / \mathrm{ml}\right)$ were diluted into the on ranging final volume from $50 \%$ to $0.4 \%$ in three trials. Bacterial growth was recorded after incubation of test tubes at $37^{\circ} \mathrm{C}$ overnight. Results from the experiment were subjected to statistical analyses using ANOVA test by using SPSS 20 software for Windows. The present study identified henna as source of biological antimicrobial properties, since it showed a high activity against L. acidophilus and S. mutans. Results show decreased S. mutans growth with increase in concentration of Lawsonia inermis extract. Result show that even the highest concentration of Lawsonia inermis extract does not completely inhibit $S$. mutans growth although bacterial growth on medium with $50 \%$ extract was very low.
\end{abstract}

\section{Introduction}

The increasingly high numbers of bacteria that are developing resistance to classical antibiotics drive much of the current interest on plant antimicrobial molecules in hope that they may provide useful leads into anti-infective drug candidates ${ }^{[1,2,3]}$. Several antimicrobial agents were isolated from plant including secondary metabolites as essential oil and terenoides, amongst which can be cited xanthones, benzophenones, coumarins and flavonoids ${ }^{[4,5,6]}$. Henna or Hina (Lawsonia inermis, syn. L. alba) is a flowering plant, $2-6 \mathrm{~m}$ in height. Henna, Lawsonia inermis, produces a burgundy dye molecule, lawsone ${ }^{[7]}$. This molecule has an affinity for bonding with protein, and thus has been used to dye skin, hair, fingernails, leather, silk and wool. The dye molecule, lawsone, is primarily concentrated in the leaves. The main uses of henna is as a cooling agent, astringent, anti-fungal and anti-bacterial herb for the skin and hair ${ }^{[8,9]}$. The plant constituents are made up of mannite, tannic acid, mucilage and gallic acid, but the main constituent is 2-hydroxynaphthoquinone (lawsone), known to be the major bioactive constituent, dried powdered leaves of henna contain about $0.5-1.5 \%$ lawsone. Henna is naturalized and cultivated in the tropics of America, Egypt, India, Iran and parts of the midlle east ${ }^{[10,11]}$. The leaves of henna are useful to bring down the severity of many medical problems like dysentery, diseases of the spleen, lumbago, bronchitis and syphilitic eye infection ${ }^{[11]}$. The current study investigates the antimicrobial effect of Lawsonia inermis extract against two oral microorganisms. Streptococcus mutans is a facultatively anaerobic, Gram-positive coccus-shaped bacterium commonly found in the human oral cavity and is a significant contributor to tooth decay ${ }^{[12,13]}$. Early colonizers of the tooth surface are mainly Neisseria spp. and streptococci, including S. mutans. The growth and metabolism of these pioneer species changes local environmental conditions, thereby enabling more fastidious organisms to further colonize after them, forming dental plaque ${ }^{[14]}$. L. acidophilus is a homo fermentative species, fermenting sugars into lactic acid, and grows readily at rather low $\mathrm{pH}$ values ${ }^{[15]}$. The lactobacillus acidophilus is usually found in the cavitated area of a tooth. This is because the lactobacillus acidophilus is not very adhesive. However, once it colonizes, it speeds up the decaying process.

This study aims to answer whether Lawsonia inermis has antibacterial effect on S. mutans and L. acidophilus and if Lawsonia inermis has staining effect on tooth colour.

\section{Methodology}

\section{Antibacterial Assessment: Bacterial strains}

Bacterial strain was purchased from the University of the Philippines, Diliman, Quezon City, Philippines, with transfer and growth media. 


\section{Lawsonia inermis extracts preparation}

$100 \mathrm{~g}$ air dried material of leaves and seed were ground to a fine powder with pestle and mortar. $100 \mathrm{~g}$ powder was extracted with $200 \mathrm{ml} 70 \%$ ethanol for three days, with frequent agitation. The ethanol extract was filtered through Whatmann No.1 paper and filtrates were collected and centrifuged at $10000 \mathrm{rpm}$ for $10 \mathrm{~min}$ and supernatant collected. Supernatant was heated in water bath at $48^{\circ} \mathrm{C}$ to evaporate its liquid content. The extract was preserved at -20 degrees until use.

\section{Antimicrobial effect of Lawsonia inermis extract broth dilution method:}

Lawsonia inermis extract was serially diluted in sterile MRS broth from in range of $50 \%$ to $0.4 \%$ in $5 \mathrm{ml}$ sterile test tubes with a cotton plug. Plant extracts were mixed with MRS Broth as a stock solution and bacterial suspension $\left(1 \times 10^{7} \mathrm{cfu} / \mathrm{ml}\right)$ were diluted into the on ranging final volume from $50 \%$ to $0.4 \%$ in three trials. Bacterial growth was recorded after incubation of test tubes at $37^{\circ} \mathrm{C}$ overnight. Bacteria in MRS broth were used as negative control for bacterial assay. All experiments were conducted as triplicate.

\section{Photometric Assessment:}

\section{Photometric assessment of Lawsonia inermis extract on tooth color:}

Effect of Lawsonia inermis extract on tooth color was assessed by using a modified technique of Denissen et al., (2010). Nineteen Canine teeth were taken to evaluate staining effect of Lawsonia inermis extract on enamel color. Teeth structure investigated with $4 \mathrm{X}$ magnifier and transillumination to make sure that they were free of cracks, fracture and caries in cervical or root area. Then the teeth were placed in $10 \%$ formalin solution for disinfection. Teeth were kept hydrated at room temperature in distilled water prior to the study and during tooth preparation each tooth was wrapped with water moistened gauze before placing in different concentrations of Lawsonia inermis extract. Then teeth were placed into $6 \mathrm{ml}$ of different concentrations of Lawsonia inermis extracts for 48 hours. Canine teeth were digitalized before and after placement onto Lawsonia inermis extract using LSR digital camera (Canon IXUS 970 IS). Digital camera was fixed at a distance of $13 \mathrm{~cm}$ from the teeth and the process was done under fluorescent light, then digital image were imported into database of Gimp 11.0 software to investigate the tooth color change using luminosity value.

\section{Statistical Analysis:} Windows

Results from the experiment were subject to statistical analyses using ANOVA test by SPSS 20.0 for

\section{Results}

Result show a significant difference between inhibitory effects of Lawsonia inermis extracts to a significance level of $\mathrm{p}=0.01$.

Table 1: Result of one way ANOVA test

\begin{tabular}{|c|c|c|c|c|c|}
\hline & Sum of Squares & df & Mean Square & F & Sig. \\
\hline Between Groups & 0.75 & 8 & 0.094 & 9.374 & 0.001 \\
\hline Within Groups & 0.18 & 18 & 0.01 & & \\
\hline Total & 0.93 & 26 & & & \\
\hline
\end{tabular}

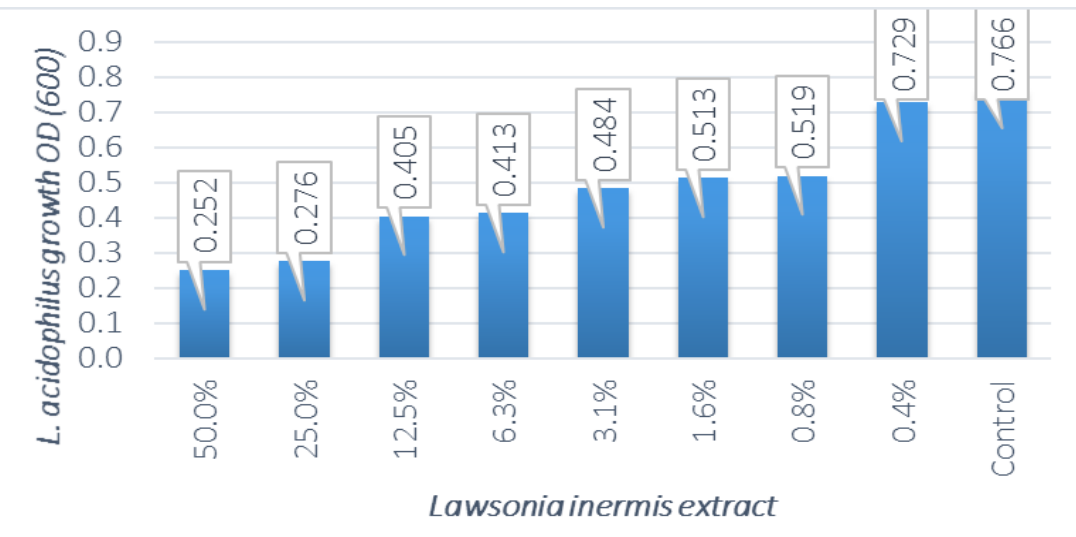

Figure 1: Effect of Lawsonia inermis extract on L. acidophilus 


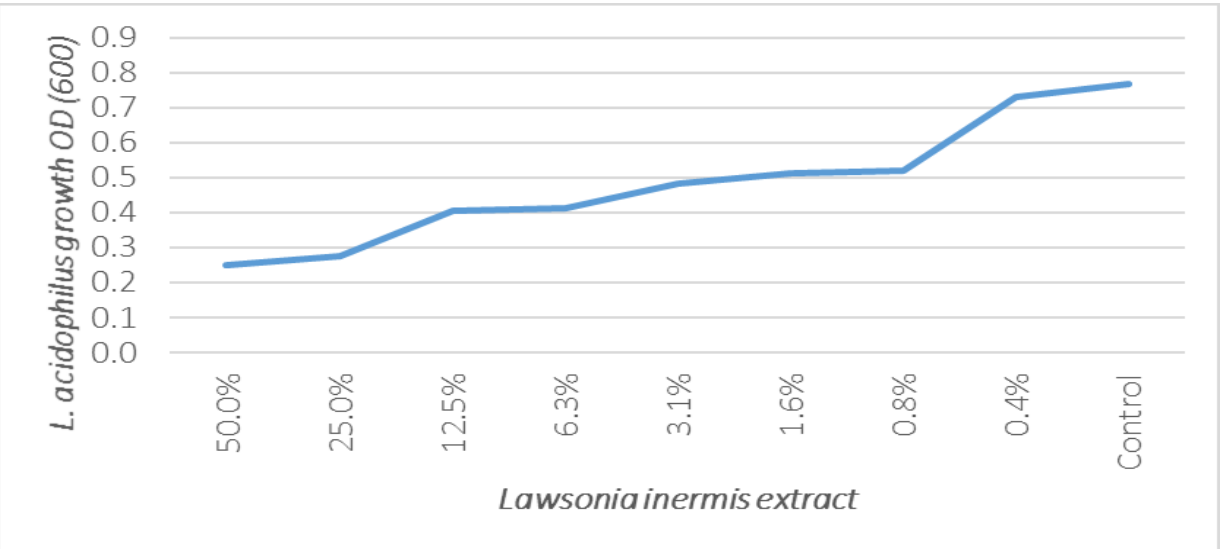

Figure 2: Effect of Lawsonia inermis extract on L. acidophilus growth

Result show decrease in concentration of L.acidophilus with increased concentrations of Lawsonia inermis extract (Fig. 1 \& 2). Even highest concentration of Lawsonia inermis extract does not completely inhibit L. acidophilus growth (Fig. 1) but has great antibacterial activity.

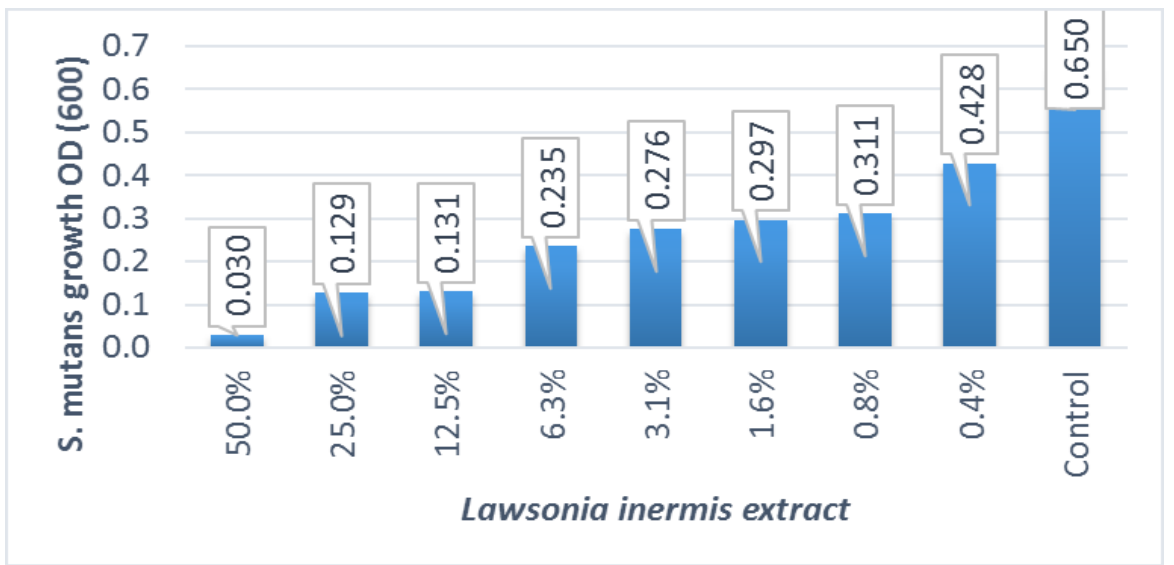

Figure 3: Effect of Lawsonia inermis extract on S. mutans growth

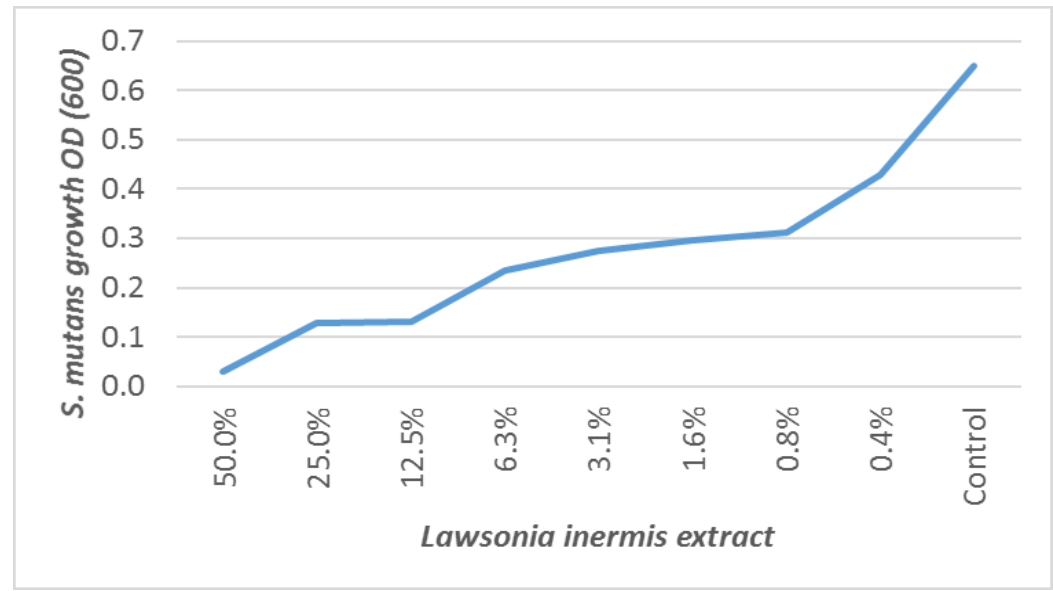

Figure 4: Effect of Lawsonia inermis extract on S. mutans growth

Result show decreased S. mutans growth with increase in concentration of Lawsonia inermis extract (Fig. 4). Result show that even highest concentration of Lawsonia inermis extract does not completely inhibit S. mutans growth although bacterial growth on medium with $50 \%$ extract was very low (Fig. 3).

Depending on different concentrations of Lawsonia inermis extract the dentin color intensity increased from low concentration of Lawsonia inermis extract $(0.4 \%)$ and reached to highest intensity at $50 \%$ Lawsonia inermis extract. Also result shows that enamel color does not change visually (Fig. 5). 


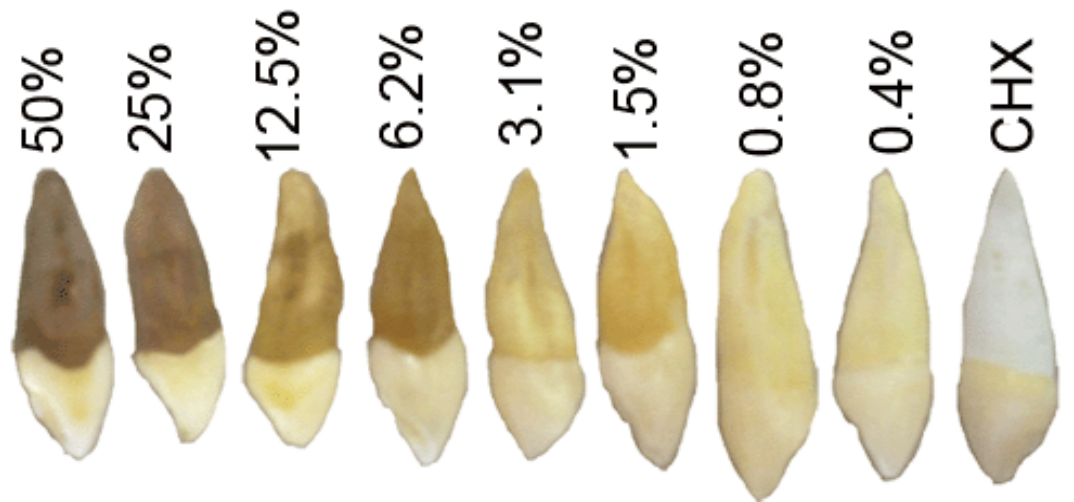

Figure 5: Effect of Lawsonia inerrmis extract on tooth color

Result of photometric analysis show that by increase in concentration of Lawsonia inermis extract, luminosity of the dentin on an average decreased from $201.78 \mathrm{~L}$ to $110.99 \mathrm{~L}$ in comparison to the control(with Ora hex mouth wash) (Fig. 6), but in comparison to the control, the luminosity of enamel does not change visually(Fig. 7).

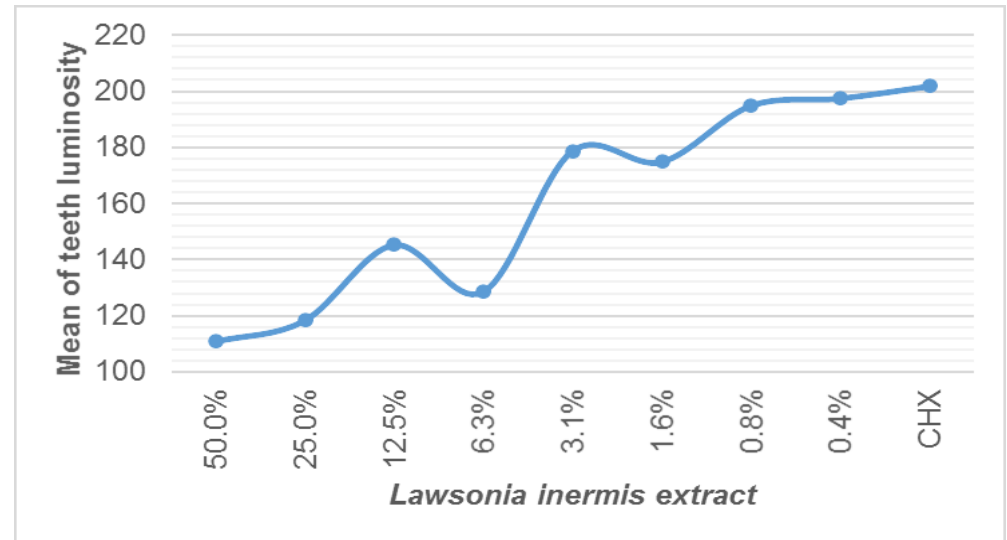

Figure 6: Effect of Lawsonia inermis on dentin luminosity

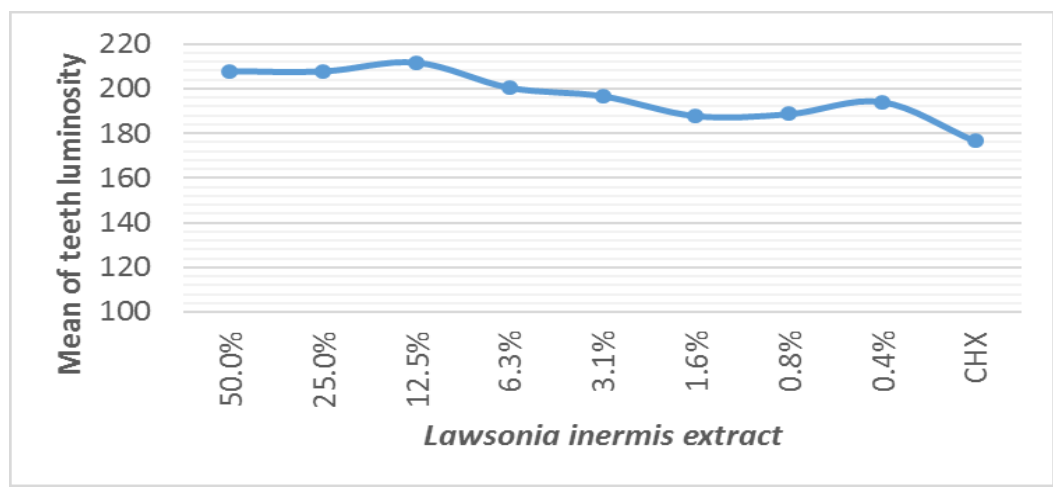

Figure 7: Effect of Lawsonia inermis on enamel luminosity

\section{Discussion}

The present study identifies Henna (Lawsonia inermis) as source of biological antimicrobial, since it showed high activity against L. acidophilus and S. mutans. Quinones are present in henna. These are aromatic rings with two ketone substitutions. They are ubiquitous in nature and are characteristically highly active. These compounds, being colored are responsible for the coloring reaction in cut or injured fruits and vegetables and are an intermediate in the melanin synthesis pathway in human skin ${ }^{[16]}$. It is the presence of quinones in henna that gives the material its dyeing properties ${ }^{[17]}$. The switch between diphenol and quinone occurs easily through oxidation and reduction reactions. The individual redox potential of the particular quinone-hydroquinone pair is very important in many biological systems. Hydroxilated amino acids may be made into quinones in the presence of suitable enzymes, such as a polyphenoloxidase ${ }^{[18]}$. In addition to providing a source of stable free 
radicals, quinones are known to complex irreversibly with nucleophilic amino acids in proteins often leading to inactivation of the protein and loss of function ${ }^{[19]}$. For this reason, the potential range of quinone antimicrobial effects is great. Portable targets in the microbial cell are surface-exposed adhesions, cell wall polypeptides, and membrane-bound enzymes. Quinones may also render substrates unavailable to the microorganism.

\section{Conclusion}

It is clear that Lawsonia inermis leaves, as an extract may be useful as an antimicrobial agent against $\mathrm{L}$. acidophilus and S. mutans. Also result show that Lawsonia inermis extract can be an excellent indicator for dentin exposure and identification of cracked teeth in the patient's mouth and high concentration of Lawsonia inermis extract may help in rapid identification of cavities and exposed dentin.

\section{Recommendations}

Isolation of the active ingredients and bioactive flavonoids from Lawsonia inermis to facilitate further studies are recommended. Further studies need to be undertaken regarding toxicity, safety and absorption pattern of the active ingredients on tooth surface and allergenicity of Lawsonia inermis extract. Also further study on antimicrobial effect of Lawsonia inermis extract on other oral micro biota is recommended.

\section{References}

[1] Walsh, C. Molecular mechanism that confer antibacterial drug resistance.2000, Nature, 406 (2), $775-781$.

[2] Kiessling, C. R., Bennit, M. H. J., Loftis, M., Kissling, V. W., Data, A. R. \& Soos, J. N. 2002. Antimicrobial resistance of food retailed Salmonella isolates. Journal of Food Protection, 65(3), 603-608.

[3] Cole, A. M., Hong, T., Nguyen, T., Zhae, C., Bristol, G., Zack, J. A., Waring, A. J. \& Yang, O. O. 2002. Retrocyclin: A primate peptide that protects cells from infection by T- and M-tropic strains of HIV-1. Proceedings of the National Academy of Sciences, 99(5), 1813-18.

[4] Nkengfack, A. E., Mkounga, P., Meyer, M., Fomum, Z. T., Bodo, B. 2002. Globulixanthones C, D and E: Three prenylated xanthones with antibacterial properties from the root bark of Symphonia globulifera. Phytochemistry, 6(1), $181-187$.

[5] Ouahouo, B. M., Azebaze, A. G., Meyer, M., Bodo, B., Fomum, Z. T. \& Nkengfack, A. E. 2004. Cytotoxic and antimicrobial coumarins from Mammea Africana. Annals of Tropical Medicine and Parasitology, 98(2), 733-739.

[6] Komgeum, J., Meli, A. L., Manfou, R. N., Lontsi, D. Ngounou, F. N. Kuete, V., Kamdem, H. W. P. \& Ngadjui, B.T. 2005. Xanthones from Garcinia smeathmannii (Oliver) and their antimicrobial activity. Phytochemistry, 66(2), 1713-17.

[7] Harborne, S. B. \& Baxter, A. 1995. Phytochemical Dictionary: A handbook of bioactive compounds from plants. London: Tylor and Francis.

[8] Singh, M., Jindal, S. K., Kavia, Z. D., Jangid, B. L. \& Khem, C. 2005.Traditional Methods of Cultivation and Processing of Henna. Henna, Cultivation, Improvement and Trade Jodhpur, India. Central Arid Zone Research Institute, 69(3), 241-246.

[9] Kelmanson, J. E., Jäger, A. K. \& van Staden, J. Z. 2000. Medicinal plants with antibacterial activity. Journal of Ethnopharmacol, 69(3), 241-246.

[10] Muhammad, H. S. \& Muhammad, S. 2005.The use of Lawsonia inermis Linn. (henna) in the management of burn wound infections. African Journal of Biotechnology, 4(9), 934-37.

[11] Bhuvaneswari, K., Gana -Poongothai, S., Kuruvilla, A. \& App ala Raju, B. 2002. Inhibitory concentrations of Lawsonia inermis dry powder for urinary pathogens. Indian Journal of Pharmacology, 34(9), 260-63.

[12] Ryan, K. J. \& Ray, C. G. (2004). Sherris Medical Microbiology. (4th ed). McGraw-Hill Medical.

[13] Loesche, W. J.1996. Microbiology of Dental Decay and Periodontal Disease. Baron's Medical Microbiology. (4th ed).

[14] Vinogradov, A. M., Winston, M., Rupp, C. J. \& Stoodley, P. 2004. Rheology of biofilms formed from the dental plaque pathogen Streptococcus mutans. Biofilms 1, 49-56.

[15] Bâati, L. L., Fabre-Gea, C., Auriol, D. Blanc, P. J. 2000. Study of the cryotolerance of Lactobacillus acidophilus: Effect of culture and freezing conditions on the viability and cellular protein levels. International Journal of Food Microbiology, 59(3), 241-247.

[16] Scherer, D., Kumar, R. 2010. Genetics of pigmentation in skin cancer-a review. Mutation Research, 705(2), 141-153.

[17] Fessenden, R. J. \& Fessenden, J. S. 1998. Fessenden's organic chemistry. (6th ed). California: Cole Publishing Inc.

[18] Thastrup, O., Knudsen, J. B., Lemmich, J. L. \& Winther, K. 1985. Inhibitions of human platelet aggregation by dihydropyranoand dihydrofurano-coumarins, a new class of cAMP phosphodiesterase inhibitors Biochem Pharmacol, 34(2), 2137-40.

[19] Tan, A. S. \& Berridge, M. V. 2008. Differential effects of redox-cycling and arylating quinones on trans-plasma membrane electron transport Biofactors, 34(3), 183-190. 